\title{
Evaluation of functional capacity and level of physical activity in adolescent and adult patients with cystic fibrosis
}

\author{
Avaliação da capacidade funcional e do nível de atividade física em \\ pacientes adolescentes e adultos com fibrose cística
}

\author{
Inaê Angélica Cherobin¹, Paulo de Tarso Roth Dalcin 1,2, Bruna Ziegler 1,2
}

\begin{abstract}
The objective of the present study was to compare the functional capacity and level of physical activity between adolescent and adult patients with cystic fibrosis (CF) and healthy individuals. The six-minute walk test (6MWT) was used to evaluate functional capacity and the International Physical Activity Questionnaire (IPAQ - long version) was applied to assess physical activity level. This study included 31 patients with CF (11 males and 20 females) and 31 healthy individuals. Patients with CF had significantly lower values of body mass index (BMI), pulmonary function parameters, physical activity level, six-minute walking distance (6MWD) and peripheral oxygen saturation $\left(\mathrm{SpO}_{2}\right)$. Comparing patients using a cut-off point of $500 \mathrm{~m}$, there were no significant differences in the classification of physical activity level assessed by the IPAQ questionnaire. Among patients with $\mathrm{CF}$ who walked less than $500 \mathrm{~m}$, there were significantly lower values of peak expiratory flow (PEF), PEF (\%), $\mathrm{SpO}_{2}$ after 6MWT and distance walked in the $6 \mathrm{MWD}$. It could be concluded that patients with CF practice physical activity at lower levels than healthy individuals, when compared by the IPAQ questionnaire.
\end{abstract}

\section{Keywords}

Cystic Fibrosis; International Physical Activity Questionnaire; 6 Minute Walk Test.

\section{Resumo}

$O$ objetivo deste estudo foi comparar a capacidade funcional e $o$ nivel de atividade física de pacientes adolescentes e adultos com fibrose cística (FC) e indivíduos sadios. Para a avaliação da capacidade funcional foi utilizado o teste de caminhada de 6 minutos (TC6M) e para a verificação do nível de atividade física, foi utilizado o Questionário Internacional de Atividade Física (IPAQ - versão longa). Participaram do estudo 31 indivíduos com FC (11 do sexo masculino e 20 do sexo feminino) e 31 individuos sadios. Os pacientes com FC apresentaram valores significativamente mais baixos de indice de massa corporal (IMC), parâmetros de função pulmonar, nível de atividade física, distância percorrida no teste de caminhada de 6 minutos e saturação periférica de oxigênio $\left(\mathrm{SpO}_{2}\right)$. Comparando os pacientes através ponto de corte $500 \mathrm{~m}$, não bouve diferenças significativas na classificação do nível de atividade física avaliada pelo questionário. Nos pacientes com FC que caminharam abaixo de $500 \mathrm{~m}$, observaram-se valores significativamente menores de pico de fluxo expiratório (PFE), $\mathrm{PFE}(\%), \mathrm{SpO}_{2}$ após TC6M e distância percorrida no teste de TC6M (DTC6M). Podemos concluir com este estudo que indivíduos com FC praticam atividade física com intensidades mais baixas que individuos sadios quando comparados pelo IPAQ.

\section{Palavras-chave}

Fibrose cística; Questionário Internacional de Atividade Física; Teste de caminhada de 6 minutos.

\section{Introduction}

Cystic fibrosis (CF) is a recessive autosomal genetic disorder, more frequent in the white population, characterized by chronic pulmonary infection, exocrine pancreatic insufficiency and high electrolyte concentration in sweat. This disease shows great variability in

1 Universidade Federal do Rio Grande do Sul (UFRGS). Programa de Pós-Graduação em Ciências Pneumológicas. Porto Alegre, RS, Brazil.

2 Hospital de Clínicas de Porto Alegre the pattern of organic impairment, severity and complications. Pulmonary impairment is the main responsible for morbidity and mortality in these patients ${ }^{1}$.

As the disease progresses, there is impairment of pulmonary function, caused by recurrent infections, airway obstruction, pulmonary hyperinflation and bronchiecstasy ${ }^{2}$. Pulmonary diseases predominate at the apices, mainly on the right side, where parenchymal infiltrations, atelectasis areas and acute and chronic al- 
veolar condensations can be observed. Pneumothorax is a complication frequently associated with the development of cystic fibrosis ${ }^{3}$. In the final stages of this disease, there is extensive parenchymal destruction, pulmonary hypertension and cor pulmonale. At this moment, pulmonary transplant is definitely a therapeutic option ${ }^{4}$.

Reduction in exercise capacity is frequently found in patients with CF. Lack of physical fitness has a multifactorial nature and it is associated with pulmonary disease, malnourishment, increase in energy demands and musculoskeletal changes ${ }^{5}$. With the development of this disease, symptoms associated with intolerance to exercise are triggered with increasingly lower physical efforts, causing restriction to activities of daily life and reducing quality of life ${ }^{6}$.

Physical activities must be performed regularly and they are an essential part of CF treatment ${ }^{7}$. Patients who practice regular physical activities and use enzymes, antibiotic therapy and respiratory physiotherapy concomitantly show improvement in mucociliary depuration, body composition, bone development, immunological function and maximal oxygen uptake ${ }^{8}$. Additionally, they show a reduction in protein degradation, production of lactic acid, resistance to insulin and resting heart rate ${ }^{8}$. Stretching and aerobic exercises can also contribute to the improvement of posture and quality of life $\mathrm{e}^{9,10}$.

The assessment of the capacity to exercise in patients with CF is usually performed through the six-minute walk test $(6 \mathrm{MWT})$ or maximal effort test ${ }^{11}$. The $6 \mathrm{MWT}$ is the one most frequently used in clinical practice and it is performed regularly in six-month or annual evaluations of patients with CF. Moreover, during each routine outpatient consultation, it is recommended that patients should be asked about adherence to treatment and encouraged to do this through physical activity, among other things. Until now, there have been no specific instruments to assess physical activity in the population of patients with CF. The International Physical Activity Questionnaire (IPAQ) is a validated and reproducible instrument used to measure physical activity level, which can be quickly and easily applied ${ }^{12}$.

The present study aimed to compare the functional capacity and physical activity level between adolescent and adult patients with cystic fibrosis and healthy individuals. Additionally, it was aimed at associating functional capacity and physical activity level with clinical, nutritional and pulmonary function aspects of patients with cystic fibrosis.

\section{Methods}

A cross-sectional study was performed to assess the physical activity level of 31 patients with CF and 31 healthy individuals with similar characteristics of sex, age and ethnicity.

Patients with CF were being followed through the Program for Adolescents and Adults with CF of the Hospital de Clínicas de Porto Alegre (HCPA -City of Porto Alegre Clinical Hospital), RS, Southern Brazil. The inclusion criteria were as follows: to be aged more than 15 years; and to have been diagnosed with CF, confirmed through clinical history and sweat test (chloride higher than $60 \mathrm{mmol} / \mathrm{L}$ ) in at least two samples or through genetic study with the identification of two mutations known to be the cause of CF. Patients with CF should be clinically stable, defined by the absence of recent changes (last 30 days) in medication or at least 30 days since the end of the last cycle of oral or intravenous antibiotics for pulmonary exacerbation. The exclusion criteria for CF were as follows: pregnancy; and cardiovascular, orthopedic or trauma alterations that could restrict test performance. A total of three patients with CF refused to participate in this study. 
A healthy individual was included for each patient with CF, with similar characteristics of sex, age and ethnicity. These individuals were recruited through posters put up at the HCPA and through online advertising. The group of healthy individuals underwent a medical evaluation and the following exclusion criteria were taken into consideration: pregnancy, acute respiratory symptoms, current or past smoking, alterations in pulmonary function, asthma, and cardiovascular and orthopedic conditions that prevent the performance of tests. A total of two individuals were excluded from the healthy group as they had altered spirometry results.

The International Physical Activity Questionnaire (IPAQ) was used to assess physical activity level. Individuals responded to questions about activities performed during the week, in the workplace, at home, while using means of transport and during leisure time ${ }^{13}$. They were categorized according to physical activity level. Those practicing vigorous activities on at least three days of the week (or combinations equivalent to $3000 \mathrm{MET}$-minute/week) were placed in the high-intensity group; those practicing vigorous activity on three or more days for at least 20 minutes (or combinations equivalent to 600 MET-minute/week) were in the moderate-intensity group; and those whose activity level did not correspond to any of the above mentioned categories were in the low-intensity group ${ }^{14}$.

All individuals included in this study were submitted to the six-minute walk test (6MWT), which was performed according to the guidelines from the American Thoracic Society (ATS). ${ }^{15}$ This test was performed on a 30-meter-long flat surface marked at every three meters. Patients were exposed to verbal stimuli standardized during the test and instructed to walk around as many laps as possible during six minutes, maintaining their regular walking pace. At the beginning and end of the test, data on arterial pressure, heart rate, respiratory rate, Borg score for dyspnea and fatigue in the lower limbs and peripheral oxygen saturation (SpO2) were obtained. The distance walked was recorded at the end of the $6 \mathrm{MWT}^{15}$.

All individuals participating in this study were submitted to a pulmonary function evaluation with spirometry, performed in the Pulmonary Physiology Unit of the HCPA's Pulmonology Service, while patients were in a sitting position, using the Master Screen, Jaeger - version 4.31a (Jaeger, Wuerzburg, Germany), and following the technical acceptability criteria from the 2002 Guidelines for Pulmonary Function Tests of the Brazilian Thoracic Society ${ }^{16}$. A total of three technically acceptable successive forced expiratory curves are performed and the one showing the highest value is recorded. The following parameters were measured: forced expiratory volume in the first second $\left(\mathrm{FEV}_{1}\right)$, forced vital capacity $(\mathrm{FVC}), \mathrm{FEV}_{1} / \mathrm{FVC}$ ratio and peak expiratory flow (PEF). Values were expressed in liters and percentages of what was expected for sex, age and height ${ }^{17}$.

All individuals were submitted to a nutritional evaluation for their body mass index (BMI) to be calculated. Weight was measured with a Filizola electronic scale. Patients were weighed while wearing light clothing and no shoes. Height was measured with the digital scale's anthropometer. Patients should not be wearing shoes or hats and they should be standing on the platform with their heels together and their body as straight as possible. Heels, buttocks, shoulders and head should touch the anthropometer's vertical surface. The patient's line of vision should be on the horizontal plane. BMI was obtained by dividing one's current weight (in kilograms) by the square of one's height (in meters) $\left(\mathrm{BMI}=\right.$ weight $/$ height $\left.^{2}\right)$. BMI was considered to be normal when the percentile was > 25; at a nutritional risk, when it was between 10 and 25; and malnourishment, when it was $<10^{18}$. 
The clinical evaluation of the Shwachman-Kulczycki (S-K) score was performed for patients with CF. This clinical evaluation system includes four different characteristics (general activity, physical examination, nutrition and chest $\mathrm{X}$-ray findings), which were individually ranked according to a scale from five to 25 points (the better the performance, the higher the score), so that a final score of 100 points meant a patient in excellent clinical conditions.

All individuals included in this study signed an informed consent form. Researchers used two consent forms, one for patients with CF and another for healthy individuals. An authorization was requested from legal guardians of patients aged less than 18 years.

The present research project was approved by the HCPA's Scientific and Ethics Committee under number 08-063.

\section{Statistical analysis}

Data were expressed in number of cases (proportion), mean, standard deviation (SD) or median (inter-quartile deviation - ID).

Comparisons of categorical data were made using the chi-square test. The t-test for paired samples was used to compare continuous variables with a normal distribution between patients with $\mathrm{CF}$ and healthy individuals, while the t-test for independent samples was used in the analyses of patients with CF when categorized by the IPAQ and distance walked in the 6MWT.

Data analysis was performed with the SPSS program, version 18.0. The level of statistical significance was $\mathrm{p}<0.05$. All probabilities reported were two-tailed.

\section{Results}

Between January and December 2012, 34 patients with CF and 33 healthy individuals were assessed. A total of three patients with CF refused to participate in this study and two healthy individuals were excluded due to altered spirometry results. The following participants concluded the study: 31 patients with CF (11 males and 20 females) and 31 healthy individuals. Mean age was 25.6 years among patients with CF and 26.1 years among healthy individuals.

Table 1 shows the general characteristics of patients with CF, compared to healthy individuals. Patients with CF had significantly lower BMI values, pulmonary function parameters, physical activity level and some 6MWT parameters, such as basal heart rate, basal respiratory rate, basal SpO2, post-test SpO2, $\Delta$ $\mathrm{SpO} 2$ and 6MWD.

Table 2 shows the clinical and functional characteristics of patients with CF according to the classification of physical activity level found in the IPA questionnaire. There were no statistically significant differences between groups for the variables studied.

Table 3 shows the values according to the classification of physical activity level with a cut-off point of $500 \mathrm{~m}$ in the $6 \mathrm{MWT}$. Significantly lower values were found in patients with CF with 6MWT $<500 \mathrm{~m}$ for the PEF (L) ( $\mathrm{p}=0.030)$, PEF (\%) $(\mathrm{p}=0.040), \mathrm{SpO}_{2}$ after the 6MWT and 6MWD, when compared to the group that walked $\geq 500 \mathrm{~m}$. There were no differences in terms of physical activity levels obtained through the IPAQ for the classification of physical activity level through the 6MWT. 
TABLE 1 - General characteristics of patients with cystic fibrosis, compared to healthy individuals $(n=31)$.

\begin{tabular}{|c|c|c|c|}
\hline Variable & $\begin{array}{l}\text { Healthy individuals } \\
\text { mean } \pm S D\end{array}$ & $\begin{array}{l}\text { Patients with CF } \\
\text { mean } \pm S D\end{array}$ & $p$-value \\
\hline Age (years) & $26.10 \pm 8.80$ & $25.68 \pm 8.6$ & 0.035 \\
\hline $\mathrm{BMI}\left(\mathrm{Kg} / \mathrm{m}^{2}\right)$ & $22.88 \pm 3.32$ & $20.66 \pm 2.40$ & 0.003 \\
\hline IPAQ, n (\%) & & & 0.035 \\
\hline Low & $9(29)$ & $10(32.30)$ & \\
\hline Moderate & $16(51.60)$ & $21(67.70)$ & \\
\hline High & $6(19.40)^{*}$ & $0(0)^{*}$ & \\
\hline $\mathrm{MIP}\left(\mathrm{cmH}_{2} \mathrm{O}\right)$ & $98.10 \pm 33.90$ & $92.73 \pm 27.90$ & 0.344 \\
\hline $\operatorname{MEP}\left(\mathrm{cmH}_{2} \mathrm{O}\right)$ & $109.17 \pm 25.20$ & $112.87 \pm 32.87$ & 0.518 \\
\hline FVC & $4.10 \pm 1.42$ & $2.76 \pm 1.00$ & 0.000 \\
\hline FVC (\%) & $94.41 \pm 11.48$ & $68.17 \pm 16.54$ & 0.000 \\
\hline $\mathrm{FEV}_{1}$ & $3.34 \pm 0.95$ & $1.89 \pm 0.92$ & 0.000 \\
\hline $\mathrm{FEV}_{1}(\%)$ & $93.26 \pm 12.16$ & $54.60 \pm 21.25$ & 0.000 \\
\hline $\mathrm{FEV}_{1} / \mathrm{FVC}$ & $86.03 \pm 7.45$ & $67.85 \pm 14.99$ & 0.000 \\
\hline $\mathrm{FEV}_{1} / \mathrm{FVC}(\%)$ & $86.03 \pm 7.45$ & $79.58 \pm 17.48$ & 0.096 \\
\hline \multicolumn{4}{|l|}{$6 \mathrm{MWT}$} \\
\hline Basal HR & $79.23 \pm 9.58$ & $93.58 \pm 14.84$ & 0.000 \\
\hline Post-test HR & $127.26 \pm 19.59$ & $129.26 \pm 18.39$ & 0.666 \\
\hline Basal RR & $17.35 \pm 3.54$ & $22.10 \pm 4.01$ & 0.000 \\
\hline Post-test RR & $22.81 \pm 5.23$ & $24.81 \pm 5.28$ & 0.105 \\
\hline Basal $\mathrm{SpO}_{2}$ & $98.19 \pm 0.946$ & $96.0 \pm 2.08$ & 0.000 \\
\hline Post $\mathrm{SpO}_{2}$ & $97.84 \pm 1.59$ & $92.97 \pm 5.88$ & 0.000 \\
\hline$\Delta \mathrm{SpO}_{2}$ & $0.35 \pm 1.42$ & $3.03 \pm 4.77$ & 0.007 \\
\hline $6 \mathrm{MWD}$ & $577.52 \pm 76.10$ & $517.03 \pm 99.99$ & 0.014 \\
\hline
\end{tabular}

$\mathrm{n}=$ number of cases, $\mathrm{SD}=$ standard deviation, $\mathrm{BMI}=$ body mass index, IPAQ = International Physical Activity Questionnaire, MIP = maximal inspiratory pressure, $\mathrm{MEP}=$ maximal expiratory pressure, $\mathrm{FVC}=$ forced vital capacity, $\mathrm{FEV}_{1}=$ forced expiratory volume in the first second, $6 \mathrm{MWT}=$ six-minute walk test, $\mathrm{HR}$ $=$ heart rate, $\mathrm{RR}=$ respiratory rate, $\mathrm{SpO}_{2}=$ peripheral oxygen saturation, $\boldsymbol{\Delta} \mathrm{SpO}_{2}=$ variation in peripheral oxygen saturation, $6 \mathrm{MWD}=$ distance walked in the six-minute walk test. ${ }^{*}$ Chi-square test for categorical variables; standardized adjusted residue $>1.96$ or $<-1.96$ (implies significantly different percentages).

TABLE 2 - Categorization of patients with CF according to the classification of physical activity level through the IPAQ questionnaire.

\begin{tabular}{lccc}
\hline Variable & $\begin{array}{c}\text { Mild PA } \\
n=10 \\
\text { mean } \pm \text { SD }\end{array}$ & $\begin{array}{c}\text { Moderate PA } \\
n=21 \\
\text { mean } \pm \text { SD }\end{array}$ & p-value \\
\hline Age & $\begin{array}{c}22.80 \pm 7.40 \\
20.17 \pm 2.87\end{array}$ & $20.05 \pm 9.00$ & 0.178 \\
\hline $\mathrm{BMI}\left(\mathrm{Kg} / \mathrm{m}^{2}\right)$ & $66.19 \pm 38.24$ & $70.41 \pm 18.30$ & 0.451 \\
\hline PFE $(\%)$ & $65.90 \pm 18.48$ & $69.24 \pm 15.97$ & 0.693 \\
\hline FVC $(\%)$ & $55.14 \pm 30.33$ & $54.35 \pm 16.38$ & 0.626 \\
\hline FEV $(\%)$ & $79.49 \pm 21.35$ & $79.62 \pm 16.00$ & 0.929 \\
\hline FEV $/$ FVC $(\%)$ & $93.40 \pm 25.22$ & $92.40 \pm 29.85$ & 0.985 \\
\hline MIP $\left(\mathrm{cmH}_{2} \mathrm{O}\right)$ & $108.40 \pm 39.38$ & $115.10 \pm 29.99$ & 0.928 \\
\hline MEP $\left(\mathrm{cmH}_{2} \mathrm{O}\right)$ & & & 0.607 \\
\hline $6 \mathrm{MWT}$ & $95.80 \pm 2.34$ & $96.10 \pm 1.99$ & \\
\hline Basal SpO & $90.70 \pm 6.81$ & $94.05 \pm 5.22$ & 0.719 \\
\hline Post-test SpO & & $537.24 \pm 60.22$ & 0.141 \\
\hline $6 \mathrm{MWD}$ & $474.60 \pm 149.38$ & $68.10 \pm 7.30$ & 0.104 \\
\hline S-K score & $59.50 \pm 19.40$ & 0.203 \\
\hline
\end{tabular}

$\mathrm{SD}=$ standard deviation, $\mathrm{BMI}=$ body mass index, IPAQ = international physical activity questionnaire, $\mathrm{PA}=$ physical activity, $\mathrm{PEF}=$ peak expiratory flow, $F V C=$ forced vital capacity, $F E V_{1}=$ forced expiratory volume in the first second, MIP = maximal inspiratory pressure, MEP = maximal expiratory pressure, $6 \mathrm{MWT}=$ six-minute walk test, $\mathrm{SpO}_{2}=$ peripheral oxygen saturation, $6 \mathrm{MWD}=$ distance walked in the six-minute walk test. 
TABLE 3 - Classification of physical activity level according to a cut-off point of 500m in the 6MWT.

\begin{tabular}{|c|c|c|c|}
\hline Variable & $\begin{array}{c}>500 \mathrm{~m} \\
\mathrm{n}=23 \\
\text { mean } \pm S D\end{array}$ & $\begin{array}{c}<500 m \\
n=8 \\
\text { mean } \pm S D\end{array}$ & $p$-value \\
\hline $\mathrm{BMI}\left(\mathrm{Kg} / \mathrm{m}^{2}\right)$ & $21.03 \pm 2.20$ & $19.57 \pm 2.76$ & 0.141 \\
\hline MIP $\left(\mathrm{cmH}_{2} \mathrm{O}\right)$ & $93.59 \pm 28.03$ & $90.38 \pm 29.52$ & 0.786 \\
\hline $\operatorname{MEP}\left(\mathrm{cmH}_{2} \mathrm{O}\right)$ & $113.09 \pm 32.03$ & $112.25 \pm 37.40$ & 0.952 \\
\hline PEF (L) & $5.57 \pm 1.93$ & $3.55 \pm 2.26$ & 0.030 \\
\hline PEF (\%) & $74.73 \pm 25.70$ & $52.01 \pm 17.87$ & 0.040 \\
\hline FVC (L) & $2.93 \pm 0.68$ & $2.24 \pm 1.59$ & 0.113 \\
\hline FVC (\%) & $70.75 \pm 13.42$ & $60.42 \pm 23.19$ & 0.156 \\
\hline $\mathrm{FEV}_{1}(\mathrm{~L})$ & $2.05 \pm 0.84$ & $1.44 \pm 1.07$ & 0.136 \\
\hline $\mathrm{FEV}_{1}(\%)$ & $57.56 \pm 21.93$ & $45.75 \pm 17.54$ & 0.209 \\
\hline $\mathrm{FEV}_{1} / \mathrm{FVC}$ & $68.28 \pm 14.74$ & $66.55 \pm 16.85$ & 0.797 \\
\hline $\mathrm{FEV}_{1} / \mathrm{FVC}(\%)$ & $79.93 \pm 17.02$ & $78.53 \pm 20.20$ & 0.859 \\
\hline \multicolumn{4}{|l|}{ 6MWT } \\
\hline Basal $\mathrm{SpO}_{2}$ & $96.39 \pm 2.10$ & $94.88 \pm 1.64$ & 0.075 \\
\hline Post-test $\mathrm{SpO}_{2}$ & $94.35 \pm 3.82$ & $89.00 \pm 8.84$ & 0.024 \\
\hline $6 \mathrm{MWD}$ & $560.60 \pm 33.9$ & $391.8 \pm 122.7$ & $<0.001$ \\
\hline \multicolumn{4}{|l|}{ IPAQ } \\
\hline Mild activity, n (\%) & $7(22.60)$ & $3(9.70)$ & 0.713 \\
\hline Moderate activity, n (\%) & $16(51.60)$ & $5(16.10)$ & \\
\hline
\end{tabular}

$\mathrm{SD}=$ standard deviation, MIP = maximal inspiratory pressure, MEP = maximal expiratory pressure, $\mathrm{PEF}=$ peak expiratory flow, FVC $=$ forced vital capacity, $F E V_{1}=$ forced expiratory volume in the first second, $6 \mathrm{MWT}=$ six-minute walk test, $\mathrm{HR}=$ heart rate, $\mathrm{RR}=$ respiratory rate, $\mathrm{SpO}_{2}=$ peripheral oxygen saturation, $\boldsymbol{\Delta} \mathrm{SpO}_{2}=$ variation in peripheral oxygen saturation, $6 \mathrm{MWD}=$ distance walked in the six-minute walk test.

\section{Discussion}

In the present study, 31 adolescent and adult patients with CF were compared to healthy individuals, aiming to evaluate their physical activity level with the IPAQ questionnaire. Patients with CF had physical activity levels significantly lower than those of healthy individuals. Approximately $19 \%$ of healthy individuals performed physical activities at a level above the recommendations, whereas none of the patients with CF achieved such level.

When compared to healthy individuals, patients with CF showed lower values of pulmonary function, BMI, resting $\mathrm{SpO} 2$, desaturation during the 6MWT and $6 \mathrm{MWD}$. However, the comparison between groups of activity in patients with CF did not reveal significant differences for these variables.

Rasekaba et al. analyzed the physical activity level through the IPAQ questionnaire in 101 individuals with CF, a mean age of 29 years and $\mathrm{FEV}_{1}$ of $101 \%$ of what is expected. As a result, they observed that patients with CF performed fewer hours of physical activity per week, even though pulmonary function parameters showed normal mean values ${ }^{20}$.

Physical activity levels could also be observed with the use of more accurate resources. Aznar et al. performed a study with 113 children and adolescents aged six to 17 years, aiming to measure physical activity levels through an accelerometer in children cared for in a CF outpatient clinic. Consequently, they concluded that patients with CF performed physical activity at less vigorous levels, not reaching the recommendations for their age $e^{21}$. 
In the present study, the BMI of patients with CF did not differ when they were categorized in different physical activity levels through the IPAQ questionnaire. In contrast with our findings, previous studies have shown that malnourishment in this population is associated with impairment of pulmonary function, loss of musculoskeletal muscles, fatigue, and reduction in physical and functional capacity ${ }^{10,22-24}$.

Furthermore, the classification through the IPAQ questionnaire did not distinguish patients in terms of pulmonary function, differently from what occurred when patients were categorized according to the $6 \mathrm{MWD}$. This fact shows that the IPAQ questionnaire may not be a good option to be applied in the usual outpatient context of patients with CF, as it could not be associated with clinical, nutritional and pulmonary function data, although it may be useful to verify their physical activity level.

In the present study, patients with CF walked shorter distances in the 6MWT, when compared to healthy individuals. When a cut-off point of $500 \mathrm{~m}$ was used, individuals who walked $<500 \mathrm{~m}$ showed lower values of PEF, expected PEF $\%$ and $\mathrm{SpO}_{2}$ after $6 \mathrm{MWT}$. In a study previously performed in our center, aimed at assessing the capacity to exercise through the 6WMT in patients cared for in a program for adults with CF, 41 patients were categorized into three groups according to functional severity. As a result, there were no statistically significant differences in the distance walked between groups. However, $73.2 \%$ of patients had a lower 6MWD than the lowest threshold of normality expected ${ }^{25}$. Martin et al. followed a cohort of adult patients with CF for 12 years, aiming to obtain prognostic data through the $6 \mathrm{MWT}$. As a result, a $6 \mathrm{MWD}<475 \mathrm{~m}$ and $\mathrm{FEV}_{1} \leq 60 \%$ of what is expected were associated with pulmonary transplant or death ${ }^{26}$.

Patients in this study who had a 6MWD $<500 \mathrm{~m}$ showed higher oxygen desaturation. In a study with 88 patients with CF aged more than ten years, Ziegler et al. aimed to identify the predictive factors of oxygen desaturation during the 6MWT in patients with CF. The factors identified were resting $\mathrm{SpO}_{2}<96 \%$ and $\mathrm{FEV}_{1}<$ $40 \%$. In this sample, $15 \%$ of patients had oxygen desaturation in the $6 \mathrm{MWT}^{27}$. In a study performed with 25 adult patients with CF, mean age of 25 years and $\mathrm{FEV}_{1}$ of $69 \%$ of what was expected, Chetta et al. observed that nine out of these 25 patients had oxygen denaturation after the 6MWT. Authors considered this desaturation to be associated with lower $\mathrm{FEV}_{1}$ and $\mathrm{SpO}_{2}$ values before such test ${ }^{28}$.

The long version of the IPAQ questionnaire is a validated instrument with high reproducibility and significance to verify physical activity level in individuals aged between 18 and 65 years, widely used in different pathologies ${ }^{29}$. There are different methods to record daily physical activity, among which the 6MWT, accelerometers and questionnaires should be emphasized. Accelerometers must be given priority when compared to questionnaires to assess routine physical activity, as some questionnaires tend to overestimate physical activity levels in patients with $\mathrm{CF}^{30}$.

Questionnaires are simple and low-cost instruments that can be easily applied. However, they may not reflect the activity actually performed by patients. More objective methods such as accelerometers are less subject to bias; nonetheless, they are expensive and require costly technology, apart from being a more time-consuming evaluation system. Questionnaires that assess physical activity performed by patients with CF have not been developed yet. Thus, more adequate instruments should be developed for this population.

One of the limitations of the present study was the fact that it had a cross-sectional design, which did not enable temporal relationships between physical activity level through IPAQ and clinical characteristics to be analyzed. More- 
over, the sample was small, so that investigations in larger cohorts are required to confirm our findings.

In conclusion, this study showed that patients with CF practice physical activity at a level below that of healthy individuals. There was no association between physical activity levels through the IPAQ and clinical and nutritional characteristics, capacity to exercise and pulmonary function. A value of $6 \mathrm{MWT}<500 \mathrm{~m}$ was associated with decreased pulmonary function and lower $\mathrm{SpO}_{2}$ at the end of the test.

\section{Authors Contribution}

- Inaê Angélica Cherobin: data collect, script and review.

- Paulo de Tarso Roth Dalcin: data analysis and review.

- Bruna Ziegler: review.

\section{References}

1. Ribeiro JD, Ribeiro MÂGDO, Ribeiro AF. Controvérsias na fibrose cística - do pediatra ao especialista (Controversies in cystic fibrosis - from pediatrician to specialist). J Pediatr (Rio J). 2002;78:171-86.

2. Pryor JA, Webber BA. Fisioterapia para Problemas Respiratórios e Cardíacos (Physiotherapy for Respiratory and Cardiovascular Problems). $2^{\text {a }}$ ed. Rio de Janeiro: Guanabara Koogan, 2002.

3. Rozov T. Doenças pulmonares em pediatria: diagnóstico e tratamento (Pulmonary diseases in pediatrics: diagnosis and treatment). $2^{\mathrm{a}}$ ed. São Paulo: Atheneu, 2012.

4. Svartman FM, Andrade CF. Transplante pulmonar na fibrose cística (Pulmonary transplant in cystic fibrosis). Rev HCPA. 2011;31:238-42.

5. Balfour-Lynn IM, Prasad SA, Laverty A, Whitehead BF, Dinwiddie R. A step in the right direction: assessing exercise tolerance in cystic fibrosis. Pediatric pulmonology. 1998 p. 278-84.

6. Orenstein DM, Hovell MF, Mulvihill M, Keating KK, Hofstetter CR, Kelsey S, et al. Strength vs aerobic training in children with cystic fibrosis: A randomized controlled trial. Chest. 2004;126:1204-14.

7. Dalcin P de TR, Abreu e Silva FA de. Fibrose cística no adulto: aspectos diagnósticos e terapêuticos (Cystic fibrosis in adults: diagnostic and therapeutic aspects). J Bras Pneumol. 2008;34(2):107-117.

8. Selvadurai HC, Blimkie CJ, Meyers N, Mellis CM, Cooper PJ, Van Asperen PP. Randomized controlled study of in-hospital exercise training programs in children with cystic fibrosis. Pediatr Pulmonol. 2002;33:194-200.

9. Schindel CS, Hommerding PX, Melo DAS, Baptista RR, Maróstica PJC, Donadio MVF. Physical Exercise Recommendations Improve Postural Changes Found in Children and Adolescents with Cystic Fibrosis: A Randomized Controlled Trial. J Pediatr. 2015;166:710-16.

10. Hebestreit H, Schmid K, Kieser S, Junge S, Ballmann M, Roth K, et al. Quality of life is associated with physical activity and fitness in cystic fibrosis. BMC Pulm Med. 2014;14:26.

11. Souza FG, Jaime PJDC, da Cunha RM. Teste ergoespirométrico aplicado à prática do exercício físico: um estudo de revisão (Ergospirometric test applied to the physical activity practice: a review study). Movimenta. 2013;6:481-7.

12. Matsudo S, Araújo T, Matsudo V, Andrade D, Andrade E, Oliveira LC, et al. Questionário Internacional de Atividade Física (IPAQ): estudo de validade e reprodutibilidade no Brasil (International Physical Activity Questionnaire (IPAQ): study on validity and reproducilibty in Brazil). Rev Bras Ativ Fís Saúde. 2001;6:5-18.

13. Pardini R, Matsudo S, Araújo T, Matsudo V, Andrade E, Braggion G, et al. Validação do questionário internacional de atividade física (IPAQ-versão 6): estudo piloto em adultos jovens brasileiros (Validation of the International Physical Activity Questionnaire (IPAQversion 6): a pilot study in young and adult Brazilians). Rev Bras Ciên e Mov. 2001;9:45-51.

14. Guidelines for Data Processing and Analysis of the International Physical Activity Questionnaire (IPAQ) - Short and Long Forms. 2005.

15. American Toracic Society. ATS statement: guidelines for the six-minute walk test. Am J Respir Crit Care Med. 2002;66:111-7. 
16. Sociedade Brasileira de Pneumologia e Tisiologia. Diretrizes para testes de função pulmonar (Guidelines on Pulmonary Function Tests). 2002.

17. Miller MR, Hankinson J, Brusasco V, Burgos F, Casaburi R, Coates A, et al. Standardisation of spirometry. European Respiratory Journal. 2005. p. 319-38.

18. Borowitz D, Baker RD, Stallings V, Bachrach LK, Beall RJ, Ph D, et al. Consensus report on nutrition for pediatric patients with cystic fibrosis. J Pediatr Gastroenterol Nutr. 2002;35:246-59.

19. Shwachman H, Kulczycki LL. Long-term study of one hundred five patients with cystic fibrosis; studies made over a five- to fourteen-year period. AMA J Dis Child. 1958;96:6-15.

20. Rasekaba TM, Button BM, Wilson JW, Holland AE. Reduced physical activity associated with work and transport in adults with cystic fibrosis. J Cyst Fibros. 2013;12:229-33.

21. Aznar S, Gallardo C, Fiuza-Luces C, Santana-Sosa E, López-Mojares LM, Santalla A, et al. Levels of moderate-vigorous physical activity are low in Spanish children with cystic fibrosis: A comparison with healthy controls. J Cyst Fibros, 2013; 13(3): 335-40.

22. Davis PB. Cystic fibrosis since 1938. Am J Respir Crit Care Med. 2006. p. 475-82.

23. Zemel BS, Jawad AF, FitzSimmons S, Stallings VA. Longitudinal relationship among growth, nutritional status, and pulmonary function in children with cystic fibrosis: Analysis of the Cystic Fibrosis Foundation National CF Patient Registry. J Pediatr. 2000;137:374-80.

24. Pencharz PB, Durie PR. Pathogenesis of malnutrition in cystic fibrosis, and its treatment. Clin Nutr. 2000;19:387-94.

25. Ziegler Bruna, Rovedder PME, Lukrafka JL, Oliveira CL, Menna-Barreto SS, Dalcin P de TR. Capacidade submáxima de exercício em pacientes adolescentes e adultos com fibrose cística (Sub-maximal capacity to exercise in adolescent and adult patients with cystic fibrosis). J Bras Pneumol. 2007;33:263-9.

26. Martin C, Chapron J, Hubert D, Kanaan R, Honoré I, Paillasseur JL, et al. Prognostic value of six minute walk test in cystic fibrosis adults. Respir Med. 2013;107:1881-7.

27. Ziegler B, Rovedder PME, Oliveira CLS, Jungblut S, Abreu e Silva F; Dalcin P de TR. Preditores da dessaturação do oxigênio no teste da caminhada de seis minutos em pacientes com fibrose cística (Predictors of oxygen desaturation in the six-minute walk test in patients with cystic fibrosis). J Bras Pneumol. 2009;35:957-65.

28. Chetta A, Pisi G, Zanini A, Foresi A, Grzincich GL, Aiello M, et al. Six-minute walking test in cystic fibrosis adults with mild to moderate lung disease: Comparison to healthy subjects. Respir Med. 2001;95:986-91.

29. Craig CL, Marshall AL, Sjöström M, Bauman AE, Booth ML, Ainsworth BE, et al. International physical activity questionnaire: 12 -Country reliability and validity. Med Sci Sports Exerc. 2003;35:1381-95.

30. Savi D, Quattrucci S, Internullo M, De Biase R V., Calverley PMA, Palange P. Measuring habitual physical activity in adults with cystic fibrosis. Respir Med. 2013;107:1888-94.

ENDEREÇO PARA

CORRESPONDÊNCIA

INAÊ ANGÉLICA CHEROBIN

ina_cherobin@yahoo.com.br
Rua Alberto Torres, 111 apt 06.

Cidade Baixa - Porto Alegre, RS, Brazil

CEP 90050-080
RECEBIDO $\quad 11 / 05 / 2015$

REVISADO 12/11/2015

APROVADO 28/01/2016 